\title{
Expression and Production of Polyclonal Antibodies against Recombinant Coat Protein of Peanut bud necrosis virus
}

\author{
Sivaprasad $Y^{1,2}$, Bhaskara Reddy BV ${ }^{1 *}$, Sujitha $A^{1}$ and Sai Gopal DVR
}

${ }^{1}$ Genomics Lab, Institute of Frontier Technology, Regional Agricultural Research Station, Acharya N. G. Ranga Agricultural University, Tirupati, India ${ }^{2}$ Department of Virology, SVU College of Sciences, Sri Venkateswara University, Tirupati 517502, Andhra Pradesh, India

\begin{abstract}
In vitro gene expression strategy was used for the production of polyclonal antiserum to the coat protein (CP) of Peanut bud necrosis virus (PBNV). The GBNV CP gene from peanut isolate was cloned into PQE-30UA expression vector and transformed into Escherichia coli (M15) cells. Expression of the CP gene of GBNV was induced in vitro and recombinant protein $(\sim 34 \mathrm{KDa})$ was purified and used for immunization of rabbits to produce the GBNV-specific polyclonal antiserum. The antiserum had a titre of 1:5000 in an indirect Enzyme Linked Immunosorbent Assay (ELISA) and reacted specifically in Western blot. The resulting antiserum was used to develop an Immunocapture Reverse Transcription-Polymerase Chain Reaction (IC-RT-PCR) assay and compared its sensitivity levels with ELISA for detection of GBNV isolates. The recombinant antiserum successfully detected natural infection of GBNV in economically important crops and weed hosts from South India.
\end{abstract}

Keywords: ELISA; IC-RT-PCR; Peanut bud necrosis virus; Polyclonal antiserum; Western blotting

\section{Introduction}

Peanut bud necrosis virus (PBNV) is one of the re-emerging viral diseases on several economically important crops such as peanut, tomato, chilli, potato, sunflower, black gram, green gram, cowpea, soybean, jute, taro, cotton, carrot, onion, etc., in India. Groundnut bud necrosis virus (GBNV) also called Peanut bud necrosis virus (PBNV) is the type member of the genus Tospovirus (family Bunyaviridae) [1]. The bud necrosis disease was distributed in South and South-East Asia [2], and its cause was first identified as Tomato spotted wilt virus (TSWV) in India [3]. After characterization, the virus was identified as distinct Tospovirus and named as Groundnut bud necrosis virus (GBNV), which is placed in serogroup IV $[1,4]$. The virus particle is enveloped, quasi-spherical of $80-120 \mathrm{~nm}$ diameter and has a tripartite, single-stranded, ambisense RNA genome. The RNAs are designated L (large), $\mathrm{M}$ (medium) and S (small) and have a size of calculated 8.9, 4.8 and $2.9 \mathrm{~kb}$, respectively. They are bounded by nucleocapsid $(\mathrm{N})$ protein [5]. The L-RNA codes for the RNA-dependent RNA polymerase and is translated from the viral complementary sense RNA (vc). The m-RNA encodes a non-structural (NSm) protein in the viral (v) sense and the precursor for the glycoprotein's G1 and G2 in the VC sense. The S-RNA encodes NSs protein in the $\mathrm{V}$ sense and $\mathrm{N}$ protein in the $\mathrm{VC}$ sense.

The bud necrosis disease on groundnut under field conditions recorded yield losses up to 50 percent depending upon plant growth at the time of infection [6]. The GBNV incidence is highly variable from field to field in a season and year to year, ranging from $<1 \%$ to $>50 \%$ [7]. The GBNV cause an estimated annual loss of US\$ $\$ 89$ million in Asia [8] and 70-90\% of groundnut in India [9]. The out -breaks of bud necrosis disease caused by GBNV in tomato result yield loss up to $100 \%$ in India [10]. The GBNV is transmitted by thrips (Thrips palmi) in a persistent manner [11]. In recent times, thrips and tospoviruses have become a serious problem in various Leguminosae, Solanaceae and Cucurbitaceae crops. The bud necrosis disease is characterized by mosaic and chlorotic spots on leaves, severe necrosis of buds and petioles and affected plants are stunted. Double Antibody Sandwich (DAS)-ELISA using polyclonal antibodies to the whole virion was used for detection of TSWV isolates in plant extracts [12]. Immunocapture PCR for the detection of GBNV was reliable for the amplification of target virus sequences from peanut and other crops $[13,14]$. The RT-
PCR was developed to detect several tospovirus species, and genome reasortants were analysed to unveil the genetic factors responsible for symptoms of Watermelon silver mottle virus (WSMoV) [15]. Degenerative primers designed from conserved region of CP gene sequence from GBNV and Watermelon bud necrosis virus (WBNV) are used in diagnosis of GBNV and WBNV isolates in India [16]. The print capture RT-PCR was developed for detection of potato stem necrosis disease caused by GBNV [17]. The genetic diversity of Peanut bud necrosis virus infecting different economically important crops in South India detected by RT-PCR method [18].

The main objective of this study was to evaluate the possibility of utilizing a recombinant GBNV-CP for the production of antiserum and its diagnosis.

\section{Materials and Methods}

\section{Virus isolates and maintenance}

The GBNV infected peanut plants were collected from different places in the Indian states of Andhra Pradesh, Tamil Nadu and Karnataka. In naturally affected GBNV groundnut samples, chlorotic and necrotic ring spots on leaves and necrosis of stem and bud in peanut were observed. The bud necrosis virus infected samples were sap inoculated on cowpea (cv-C-152, a diagnostic assay host) plants using chilled $0.05 \mathrm{M}$ phosphate buffer $(\mathrm{pH} 7.0)$ containing $0.1 \%$ 2-mercaptoethanol.

Isolation of total RNA and Reverse transcription polymerase chain reaction ( $R T-P C R)$

Total RNA was isolated from $100 \mathrm{mg}$ of healthy and GBNV

*Corresponding authors: Sivaprasad Y, Genomics Lab, Institute of Frontier Technology, Regional Agricultural Research Station, Acharya N.G. Ranga Agricultural University, Tirupati, India, E-mail: bvbreddy68@gmail.com

Received March 31, 2015; Accepted June 01, 2015; Published June 04, 2015

Citation: Sivaprasad Y, Bhaskara Reddy BV, Sujitha A, Sai Gopal DVR (2015) Expression and Production of Polyclonal Antibodies against Recombinant Coat Protein of Peanut bud necrosis virus. J Plant Pathol Microbiol S1: 002. doi:10.4172/2157-7471.S1-002

Copyright: (c) 2015 Sivaprasad Y, et al. This is an open-access article distributed under the terms of the Creative Commons Attribution License, which permits unrestricted use, distribution, and reproduction in any medium, provided the original author and source are credited. 
infected groundnut (GBNV-GN) leaf samples using RNeasy Plant Minikit according to the manufacturer's instructions (Qiagen, USA). The resulting total RNA was incubated with GBNV-CP genespecific reverse primer at $65^{\circ} \mathrm{C}$ for $5 \mathrm{~min}$ and snap-chilled on ice for $2 \mathrm{~min}$. Complementary DNA (cDNA) was synthesized using Moloney Murine Leukemia Virus (M-MuLV) reverse transcriptase (Fermentas, Canada) at $42^{\circ} \mathrm{C}$ for $1 \mathrm{~h}$. The $\mathrm{CP}$ genome forward primer, 5'-ATGTCTAACGT(C/T)AAGCA(A/G)CTC-3', and reverse primer, 5'-TTACAATTCCAGCGAAGGACC-3', were used to amplify the complete N gene of GBNV [4]. Two $\mu$ l of cDNA was amplified in a $25 \mu \mathrm{l}$ reaction volume containing $2.5 \mathrm{U}$ of Taq DNA Polymerase (Fermentas, USA), 10 pmol of GBNV-CP forward and reverse primer, $2.5 \mathrm{mM}$ Magnesium Chloride $\left(\mathrm{MgCl}_{2}\right)$ and $10 \mathrm{mM}$ each deoxynucleotide triphosphates (dNTP's). PCR amplification conditions included an initial denaturation cycle of $5 \mathrm{~min}$ at $94^{\circ} \mathrm{C}$, followed by 35 cycles of denaturation for $30 \mathrm{~s}$ at $94^{\circ} \mathrm{C}$, annealing for $1 \mathrm{~min}$ at $56^{\circ} \mathrm{C}$ and extension for $1 \mathrm{~min}$ at $72^{\circ} \mathrm{C}$ with final extension for $60 \mathrm{~min}$ at $72^{\circ} \mathrm{C}$. Amplified products $(800 \mathrm{bp}$ ) were resolved following electrophoresis through $1 \%$ agarose gel containing ethidium bromide $(10 \mathrm{mg} / \mathrm{ml})$.

\section{Cloning and transformation}

The PCR product ( $800 \mathrm{bp}$ ) was eluted by QIAquick gel extraction, cloned in to vector pTZ57R/T (Fermentas, USA) and sequenced at commercial sequencecing facility at Eurofins Genomics India Pvt Ltd, Bangalore. After E. coli DH5a transformation, the positive clones were selected, cleaved with restriction enzymes BamHI and SacI (Fermentas, Canada) and sub-cloned into 6x His tagged pQE30 UA expression vector (Qiagen, USA) according to manufacturer's instructions. Recombinant clones were used to transform E. coli M15 cells containing the pREP4 repressor plasmid by following standard molecular biology protocols [19]. The recombinant clones were maintained on Luria Agar (LA) plate containing suitable antibiotics $(50 \mu \mathrm{g} / \mathrm{ml}$ Kanamycin and $100 \mu \mathrm{g} / \mathrm{ml}$ Ampicillin).

\section{Expression of CP gene and preparation of CP fractions}

To produce the recombinant CP of GBNV, a $5 \mathrm{ml}$ of overnight culture of M15 pREP4 cells containing plasmid with GBNV-CP/pQE30 construct was added to $50 \mathrm{ml}$ of LB (Luria-Bertani) broth and the culture was grown to an optimal density at $600 \mathrm{~nm}\left(\mathrm{OD}_{600}\right)$ of 0.6 and then induced with $1 \mathrm{mM}$ of IPTG (isopropyl $\beta$-D-1-thiogalactopyranoside) for $4 \mathrm{~h}$ under $200 \mathrm{rpm}$ agitation at $30^{\circ} \mathrm{C}$. Bacterial cells were harvested by centrifugation and stored at $-80^{\circ} \mathrm{C}$ until used.

The pellet obtained from the culture was re-suspended in $5 \mathrm{ml}$ of lysis buffer (10 mM Tris (pH-7.5), $100 \mathrm{mM} \mathrm{NaH}_{2} \mathrm{PO}_{4}$ and $8 \mathrm{M}$ Urea) and incubated at $4^{\circ} \mathrm{C}$. The cells were sonicated $(6 \times 10 \mathrm{~S})$ with $10 \mathrm{Sec}$ pauses at $200-300 \mathrm{~W}$ by keeping lysate on ice at all times using ultra sonicator (Sonics, USA). After centrifugation at $13,000 \mathrm{rpm}$ for $20 \mathrm{~min}$ at $4^{\circ} \mathrm{C}$, the lysed supernatant was collected and the protein expression analysed by SDS-PAGE and Western blot analysis.

\section{Sodium dodecyl sulfate polyacrylamide gel electrophoresis (SDS-PAGE)}

The pellet from $50 \mathrm{ml}$ bacterial culture was resuspended in 100 $\mu \mathrm{l}$ of Laemmli buffer, boiled for $2 \mathrm{~min}$ and aliquots were loaded on $12 \%$ polyacrylamide gel containing SDS [20]. For visualization of the separated proteins, Coomassie brilliant blue R250 was employed.

\section{Western blot analysis (Electro-Blot Immunoassay)}

The proteins were separated by SDS-PAGE were electroblotted to a nitrocellulose membrane (BioRad, USA) using wet blot apparatus
(Genei, Bangalore) according to the standard molecular biology protocols [19]. The blotted membrane was then incubated for $1 \mathrm{~h}$ in $4 \%$ Bovine Serum Albumin (BSA) in Phosphate Buffer Saline (PBS) and then washed thrice in PBS. Recombinant proteins were detected with rabbit anti-GBNV and Goat anti rabbit IgG with alkaline phosphatase was used as a secondary antibody. The bands of interest were visualized by reaction with a substrate, 5-bromo-4-chloro-3-indolyl-phosphate -nitro blue tetrazolium (BCIP/NBT) (Fermentas, USA) according to Sambrook and Russell [19].

\section{Purification of 6xHis-tagged expressed protein by Ni-NTA column chromatography}

The recombinant poly-histidine-tagged expressed protein was purified using Ni-NTA affinity column chromatography under denature conditions according to the manufacturer instructions (Qiagen, USA). The recombinant protein was analysed by SDS-PAGE [20].

\section{Antisera production}

The purified recombinant GBNV-CP fusion protein was emulsified with an equal volume of Freund's complete adjuvant for first injection and with Freund's incomplete adjuvant for subsequent three injections intramuscularly into a New Zealand white rabbit. The rabbit was first bled two weeks after the last immunization. The serum fractions were collected and stored at $-20^{\circ} \mathrm{C}$ until required.

\section{ELISA (Enzyme-linked immunosorbent assay)}

The resulting polyclonal antiserum was used to detect GBNV infection in plant samples. Direct antigen coating (DAC)-ELISA was performed using the protocol described by Clark and Bar-Joseph [21].

\section{IC-RT-PCR (Immunocapture reverse transcription polymerase chain reaction)}

The IC-RT-PCR involves the capturing of virions, the principle involved in ELISA and captured virion particles were then denatured and amplified by RT-PCR. Initially PCR vials $(200 \mu \mathrm{l})$ were loaded with $50 \mu$ l of coating buffer having homologous antiserum (polyclonal antiserum to $\mathrm{rCP}$ ) at 1:500 dilutions $(\mathrm{v} / \mathrm{v})$. Then the tubes were incubated overnight at $4^{\circ} \mathrm{C}$. After incubation the antibody coated PCR vials were washed thrice with PBS-T and the vials were loaded with crude leaf extracts prepared in extraction buffer (PBS-T containing $2 \%$ PVP) ranging from 1:50, 1:100, 1:500, 1:1000, 1:5000, 1:7000 and 1:10000 dilutions (v/v) (Table 1) and then incubated for overnight at $4^{\circ} \mathrm{C}$. After incubation, the vials were washed thrice with PBS-T and once with PBS. Similar to RT-PCR, first strand cDNA synthesis was carried involving GBNV CP-R primer and Mu-MLV RT (Fermentas, USA) following the manufacturer's protocol. The prepared cDNA was then amplified using the GBNV-CP primers by taking $2 \mu \mathrm{l}$ of cDNA. The CP gene of GBNV was PCR amplified using specific primers. In the same manner, the sensitivity of IC-RT-PCR at various dilutions of antibodies (1: 50, 1: 100, 1:500, 1: 1000, 1: 5000, 1:7000 and 1: 10000) was also evaluated (Table 2).

\section{Results}

\section{Virus isolates and maintenance}

The GBNV symptoms were first appear in the young leaflets as mosaic, chlorotic spots and mild mottle, which later develop into chlorotic and necrotic rings, streaks and extend to petioles and to terminal buds. Infection at a young age results in the death of the plant due to severe necrosis. The bud necrosis disease samples were 
Citation: Sivaprasad Y, Bhaskara Reddy BV, Sujitha A, Sai Gopal DVR (2015) Expression and Production of Polyclonal Antibodies against Recombinant Coat Protein of Peanut bud necrosis virus. J Plant Pathol Microbiol S1: 002. doi:10.4172/2157-7471.S1-002

\begin{tabular}{|c|c|c|c|c|c|c|c|c|c|c|c|c|c|}
\hline \multicolumn{14}{|c|}{ Antigen dilutions } \\
\hline \multicolumn{2}{|c|}{$1: 50$} & \multicolumn{2}{|c|}{$1: 100$} & \multicolumn{2}{|c|}{$1: 500$} & \multicolumn{2}{|c|}{ 1:1000 } & \multicolumn{2}{|c|}{$1: 5000$} & \multicolumn{2}{|c|}{$1: 7000$} & \multicolumn{2}{|c|}{$1: 10000$} \\
\hline $\mathbf{H}$ & I & $\mathbf{H}$ & I & $\mathbf{H}$ & I & $\mathbf{H}$ & I & $\mathbf{H}$ & I & $\mathbf{H}$ & I & $\mathbf{H}$ & $\mathbf{I}$ \\
\hline 0.35 & 2.87 & 0.3 & 2.77 & 0.23 & 2.43 & 0.18 & 1.98 & 0.18 & 0.8 & 0.19 & 0.5 & 0.17 & 0.3 \\
\hline
\end{tabular}

Table 1: Detection of PBNV-GN leaf antigens against 1:1000 dilutions (v/v) of IV bleed antiserum by DAC-ELISA. "A405 OD values are average values of duplicate wells.

\begin{tabular}{|c|c|c|c|c|c|c|}
\hline \multirow{2}{*}{$\begin{array}{c}\text { Antibody } \\
\text { Dilutions } \\
(\mathbf{v} / \mathbf{v})\end{array}$} & $\mathbf{H}$ & $\mathbf{I}$ & II & III & IV & V \\
\hline $1: 50$ & 0.10 & 0.70 & 2.20 & 2.33 & 2.19 & 2.18 \\
\hline $1: 100$ & 0.10 & 0.37 & 2.60 & 2.02 & 2.00 & 2.00 \\
\hline $1: 500$ & 0.08 & 0.33 & 2.44 & 2.54 & 2.23 & 2.20 \\
\hline $1: 1000$ & 0.08 & 0.25 & 2.30 & 2.50 & 2.19 & 2.10 \\
\hline $1: 5000$ & 0.07 & 0.15 & 2.00 & 2.58 & 2.74 & 2.35 \\
\hline $1: 7000$ & 0.07 & 0.10 & 0.95 & 2.34 & 2.40 & 1.98 \\
\hline $1: 10000$ & 0.07 & 0.10 & 0.86 & 1.10 & 1.0 & 0.98 \\
\hline
\end{tabular}

Table 2: Titration of antiserum from different bleeds against healthy and PBNV-GN leaf antigens by DAC-ELISA. "A405 OD values are average values of duplicate wells.

collected from the different places in South India (Andhra Pradesh, Tamil Nadu and Karnataka states). The GBNV infected peanut samples were easily sap transmitted to cowpea ( $\mathrm{Cv}-\mathrm{c}-152)$. Both localized and systemic infections were observed on cowpea plants. Three days after inoculation, the chlorotic lesions were observed on cowpea leaves, which later turned into necrotic spots, followed by veinal necrosis. Finally, leaves showed chlorotic or pale yellow in colour before senescence. Newly emerging leaves showed systemic symptoms which consisted of mild mosaic, chlorotic ring spots and necrotic spots.

\section{RT-PCR, cloning and sequencing}

In RT-PCR, a single band of expected size (800 bp) (Figure 1) corresponding to the GBNV CP gene was observed when total RNA extracted from infected tissue was used. The identity of the $831 \mathrm{bp}$ product was confirmed by cloning (pTZ57R/T vector) and sequencing. The selected clone (Groundnut-Tirupati (GN-TPT)) was sequenced and deposited in NCBI GenBank (Accession No. EF179100). The CP gene of GBNV was 831 nucleotides long and coded for a protein of 276 amino acids. The fragment was then excised by enzymes BamHI and SacI from $\mathrm{pTZ} 57 \mathrm{R} / \mathrm{T}$ vector and sub-cloned into expression vector (pQE-30 UA).

\section{Expression and purification of GBNV-CP}

The GBNV CP gene of peanut Tirupati isolate was used for further experiments. The GBNV-CP/pQE-30 construct was used to transform E. coli (M15) cells. After initial analysis of $\mathrm{rCP}$ expression by SDS-PAGE, the expression levels were again checked for the overexpression of $\mathrm{rCP}$ by $E$. coli at different concentrations of IPTG (0.1-1.0 mM ), temperature $\left(30-37^{\circ} \mathrm{C}\right)$ and with time intervals $(3-8 \mathrm{hrs})$. After determining the optimum IPTG conc. and temperature for over expression of GBNV-CP in E. coli system at different intervals of time, a mini volume $(10 \mathrm{ml})$ expression was carried out for the feasibility of its purification by Ni-NTA columns. After that the cells were harvested and the presence of GBNV coat protein band on Coomassie brilliant blue stained in SDS-PAGE with an approximate molecular mass of $34 \mathrm{kDa}$ (Figure 2). The fusion protein was confirmed using polyclonal antiserum to GBNV-CP in Western blotting as described by O'Donell et al. [22]. The non-induced clones produced much lower but visible amount of this protein, while in non-transformed E. coli no such protein was detected. The most of recombinant GBNV-CP was found in the insoluble cytoplasmic fraction, it was proved by comparison of all fractions by Western blot analysis.

\section{Production of polyclonal antiserum to a recombinant GBNV- CP}

In antisera production, the purified product was used from the expression of recombinant vector resulting from the gateway cloning with $6 \mathrm{x}$ His tag in E. coli M15. Used both inclusion bodies and recombinant $\mathrm{CP}$ from inclusion bodies, solubilised by $8 \mathrm{M}$ urea, purified on sucrose cushion. Antiserum was obtained from bleeds taken 3 weeks after the fourth injection.

\section{ELISA test}

The polyclonal antiserum from the antiserum produced against recombinant GBNV-CP was used in DAC-ELISA. The anti-GBNV-CP sera had titres of 1:5000 when tested by indirect ELISA (Table: 2). The resulting antiserum was used to detect GBNV infecting different crops (Peanut, Tomato, Chilli, Black gram, Jute, Calotropis, Taro, Onion, Cotton, Sunflower, etc). The GBNV-GN leaf antigens were tested against 1:1000 dilutions in indirect ELISA (Table: 1 ).

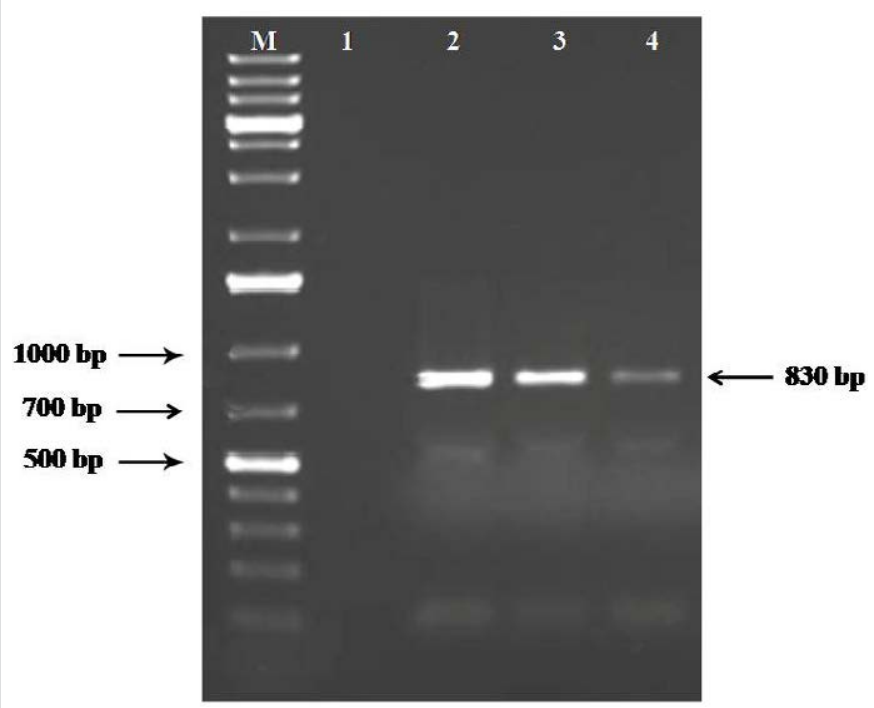

Figure 1: RT-PCR amplicons resolved by $1 \%$ agarose gel electrophoresis. Lane M: $1 \mathrm{~Kb}$ DNA Ladder; Lane 1: Healthy; Lane 2, 3, 4: PBNV infected peanut samples.

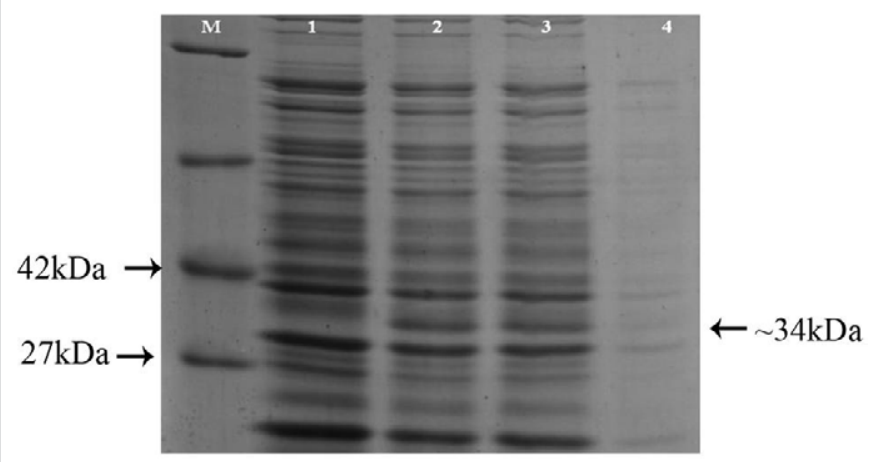

Figure 2: SDS-PAGE analysis of initial target solubility. Lane M: Protein marker; Lane 1: control; Lane 2: soluble fraction; Lane 3: insoluble fraction; and Lane 4 : uninduced fraction. 
Citation: Sivaprasad Y, Bhaskara Reddy BV, Sujitha A, Sai Gopal DVR (2015) Expression and Production of Polyclonal Antibodies against Recombinant Coat Protein of Peanut bud necrosis virus. J Plant Pathol Microbiol S1: 002. doi:10.4172/2157-7471.S1-002

\section{Western blot (Electro-Blot Immunoassay)}

In Western blot analysis, the polyclonal antiserum strongly reacted with the recombinant GBNV-CP. Western blot revealed a strong band at position corresponding to $\sim 34 \mathrm{kDa}$, which is the expected molar mass of GBNV-CP (Figure 3).

\section{Purification of expressed protein}

The recombinant poly-histidine-tagged expressed protein (GBNVCP) was purified by Ni-NTA affinity column chromatography and these fractions were analysed by SDS-PAGE and Western blot analysis. The expressed recombinant protein and purified protein have approximately molecular mass of $34 \mathrm{kDa}$ (Figure 4).

\section{IC-RT-PCR}

The recombinant coat protein antibody based IC-RT-PCR was successfully developed and tested for detection of GBNV isolates. The PCR product ( $800 \mathrm{bp}$ ) was amplified from all samples tested, but no such amplification was observed in extracts from healthy peanut plants (Figure 5a). At 1:500 dilution of rGBNV-CP based antiserum for capturing of virions, GBNV-CP was successfully amplified up to 1:5000 antigen dilutions (Figure $5 \mathrm{a}$ and $5 \mathrm{~b}$ ). Thus rGBNV-CP based polyclonal antiserum were proved to capture the virus particles even up to 1:5000 leaf antigen dilutions (v/v) as the GBNV-CP amplification by IC-RT-PCR was clearly evident up to said antibody dilution. In the same way the polyclonal antiserum produced against rGBNVCP captured GBNV virions in crude leaf extracts up to $1: 10,000 \mathrm{v} / \mathrm{v}$ antibody dilutions (Figure $6 \mathrm{a}$ and $6 \mathrm{~b}$ ).

\section{Discussion}

Peanut is one of the most important oil and food legume crop, grown in many countries of the world. It is an essential crop for smallhold farmers who grow peanut for food, oil, feed and confectionery purposes. The GBNV is easily sap-transmissible to the members of the Leguminosae, Solanaceae, Cucurbitaceae and Fabaceae was observed in localized and systemic infection.

The CP gene of GBNV isolates was initially targeted for the genetic characterization of GBNV associated with mosaic and necrosis disease of groundnut and other crops in India. Sequence analysis of the $\mathrm{CP}$ gene helps to exploit it for the production of recombinant GBNV-CP and thereby facilitates the production of rGBNV-CP based polyclonal

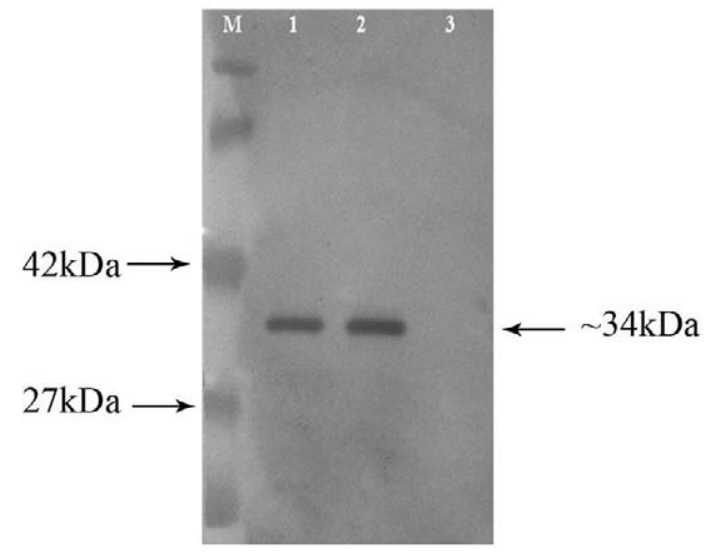

Figure 3: Western blot analysis of expressed rPBNV-CP under denatures conditions. Lane M: Prestained protein markers; Lane: 1 and $2 \sim 34 \mathrm{kDa}$ rPBNV-CP; Lane 3: uninduced control.

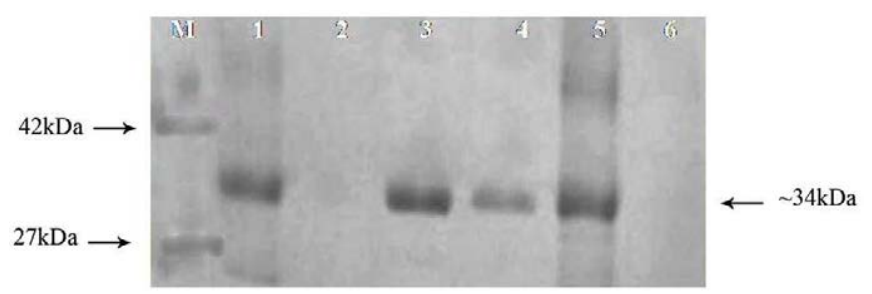

Figure 4: Western blot analysis of purified Ni-NTA columns different fractions of rPBNV-CP. Lane M: Prestained protein markers; Lane-1: Positive control; 2: Negative control; Lane 3,4,5: $\sim 34$ kDa rPBNV-CP; Lane 6: rPBNV-CP negative fraction.

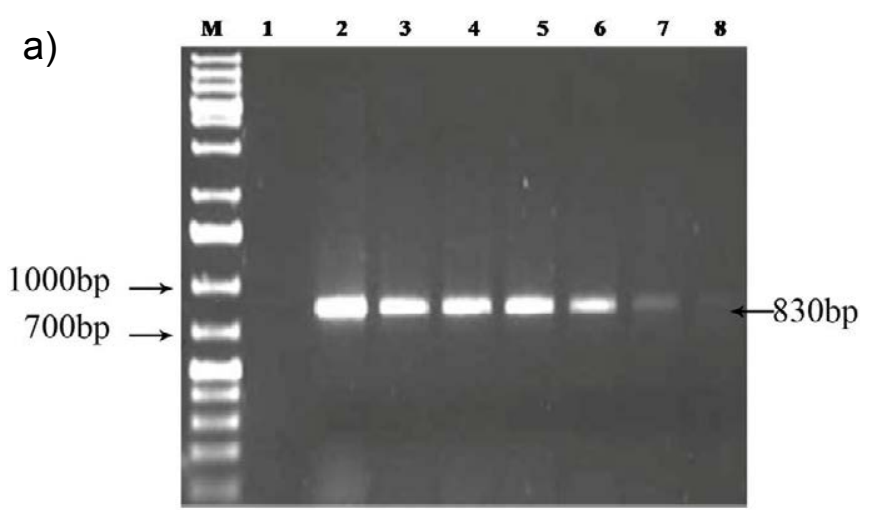

b)

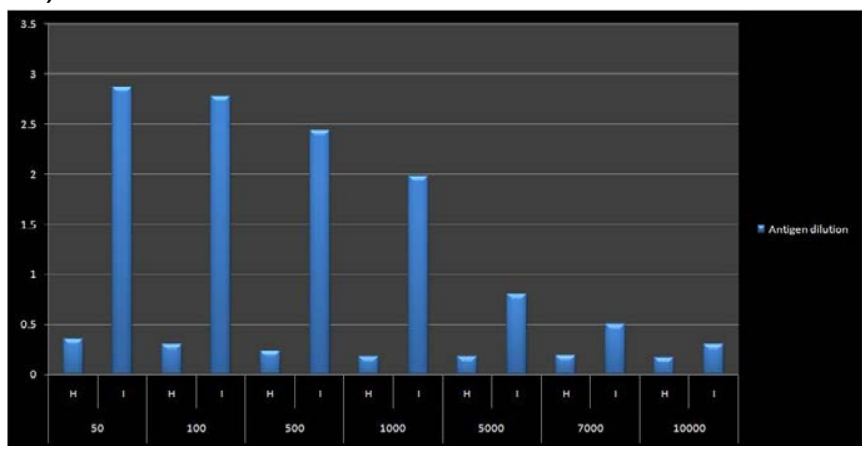

Figure 5: IC-RT-PCR analysis of PBNV-peanut isolate associated with bud necrosis disease at different dilutions of leaf extracts. Lane $M: 1 \mathrm{~Kb}$ DNA ladder, Lane 1: Healthy peanut; Lane 2 to 8 at 1:50, 1:100, 1:500, 1:1000, $1: 5000,1: 7000$ and $1: 10000$ dilutions $(\mathrm{v} / \mathrm{v})$.

antiserum for the sensitive detection of GBNV. The GBNV-CP specific primers was amplified $\sim 800$ bp of CP gene of GBNV-groundnut isolate. As the initial BLAST analysis of the obtained sequence clearly showed that the present virus isolate sequence closely related to GBNV isolates. The CP gene of GBNV revealed that sequenced region contained a single open reading frame (ORF) of 831 nucleotides that could potentially code for a protein of 276 amino acids. The sequence of Peanut-Tirupati isolate was deposited in the NCBI GenBank (Accession number EF179100). The complete sequence of GBNV-CP shared $99.6 \%$ identity at nucleotide and amino acid levels respectively with other reported GBNV isolates.

The recombinant DNA technology is an useful approach for high level expression of GBNV-CP in prokaryotic expression systems (like E. coli). Prokaryotic expression system is valuable for the production of good quality recombinant antigen based polyclonal antiserum and their 
Citation: Sivaprasad Y, Bhaskara Reddy BV, Sujitha A, Sai Gopal DVR (2015) Expression and Production of Polyclonal Antibodies against Recombinant Coat Protein of Peanut bud necrosis virus. J Plant Pathol Microbiol S1: 002. doi:10.4172/2157-7471.S1-002

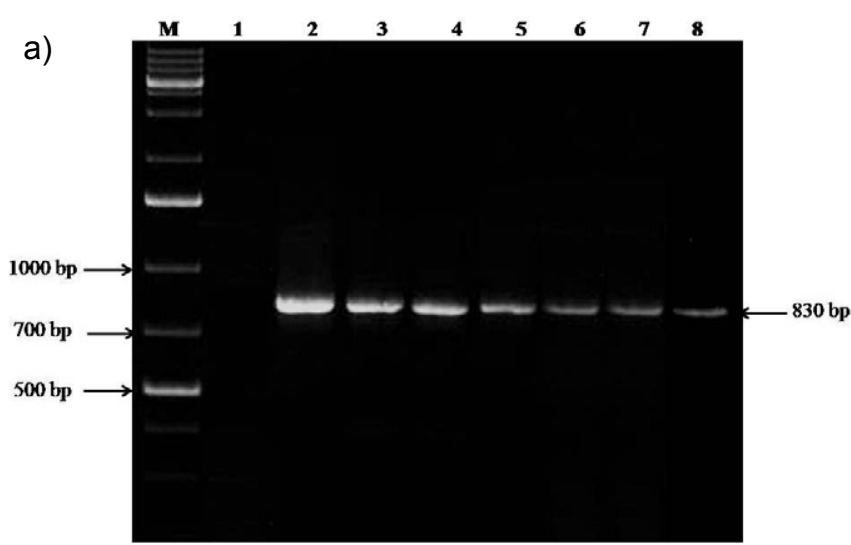

b)

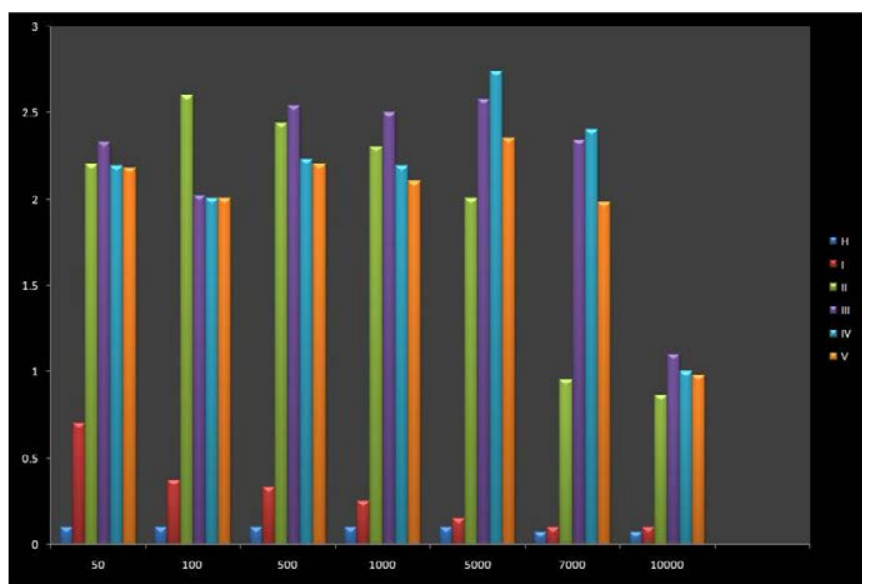

Figure 6a and b: IC-RT-PCR analysis of PBNV-peanut isolate associated with bud necrosis disease at different dilutions of recombinant antibodies. Lane M: 1Kb DNA ladder, Lane 1: Healthy peanut; Lane 2 to 8 at 1:50, 1:100, $1: 500,1: 1000,1: 5000,1: 7000$ and 1:10000 dilutions $(\mathrm{v} / \mathrm{v})$.

further exploitation in the development of sensitive antibody based serological and molecular diagnostics for detection of GBNV. Hence this approach was followed in the present study for production of $\mathrm{rCP}$ of BNV-CP based antibodies and their further use in the development of diagnostic tests for GBNV.

The conditions (IPTG conc. and temperature) were optimized for the over expression of rCP of GBNV-GN in E. coli system. The expressed rCP was purified under denaturing conditions even though the initial expressed protein was found in soluble form, because the His-tag of rCP under native conditions was noticed to be inaccessible for binding in Ni-NTA column purification. Hence the rCP of GBNV was purified under denaturing conditions using urea. The authenticity of the rCP was checked by EBIA using heterologous antibodies. The mean molecular weight of $\mathrm{rCP}$ was calculated as $\sim 34 \mathrm{kDa}$ by EBIA of crude peanut leaf extracts and amino acid sequence of $\mathrm{CP}$ gene. The urea was further removed by dialysis and the removal of urea can actually facilitate the folding of GBNV-peanut- $\mathrm{rCP}$ to its near original conformation. The protein purified under denaturing conditions does not actually affect if the purpose is antibody production [19].

However, there are several reports, the polyclonal antibodies produced against the viral proteins of Tomato spotted wilt virus [23], Grapevine leaf roll-associated closterovirus-3 is detected in ELISA [24]. Prunus necrotic ring spot virus antiserum was successful used to detect virus by DAS-ELISA in prunus [25]. Gulati-Sakhuja et al. [26] have also successfully used an antiserum produced against Pelargonium zonate spot virus recombinant CP for the detection of the virus by ELISA. Banana streak MY virus (BSMYV) antiserum (1:2000) was used in antigen coated plate-enzyme linked immunosorbent assay (ACPELISA) for the detection of virus in banana plants [27]. Alfalfa mosaic virus (AMV) polyclonal antiserum was used for the detection of virus in soybean plants in USA [28]. Our results with CP are in agreement with the results obtained for antibodies raised against recombinant Watermelon bud necrosis virus [29], Potato mop-top virus [30], Potato virus $Y$ [31], Potato virus $X[31]$.

In DAC-ELISA, the rCP based polyclonal antiserum produced against GBNV-peanut-Tirupati isolate successfully detected the GBNV-peanut isolates in crude leaf antigen up to 1:5000 (v/v) antibody dilutions ( $4^{\text {th }}$ bleed) and able to detect the GBNV in groundnut leaf extracts diluted up to 1:1000 dilution $v / \mathrm{v}$ with 1:5000 antibody dilution.

In IC-RT-PCR, the polyclonal antiserum (1:500 dilution v/v of $4^{\text {th }}$ bleed) produced against $\mathrm{rCP}$ captured the GBNV virions even up to 1:5000 v/v dilutions of crude leaf extracts. The produced antibodies were found to be highly specific in the detection of GBNV-GN isolates in crude leaf extracts (1:10 dilution w/v) by IC-RT-PCR as the virus was detected even at 1:10,000 dilution of $4^{\text {th }}$ bleed antiserum. This shows that the produced antiserum can economically be used for detection of GBNV associated with mosaic and necrosis disease of peanut and other crops also.

The GBNV in crude leaf extracts using polyclonal antiserum produced against purified GBNV up to $1: 4000 \mathrm{v} / \mathrm{v}$ antibody dilutions [29]. Similarly polyclonal antiserum was used to detect GBNV and WBNV infection in plant samples based on CP gene sequence [3235]. GBNV infection was detected from cowpea, mungbean, soybean, tomato and urdbean [16].

The antiserum produced against GBNV- $\mathrm{rCP}$ was applied successfully for the sensitive detection of GBNV in both plant and vector hosts.

\section{References}

1. Reddy DVR, Ratna AS, Sudarshana MR, Kiran K (1992) Serological relationships and purification of bud necrosis virus, a tospovirus occurring in peanut in India. Ann Appl Biol 120: 279-286.

2. Reddy DVR (1988) Groundnut virus disease occurring in India. In: Reddy PS (ed) Groundnut. Indian council of Agricultural Research, New Delhi, India, 508 525

3. Ghanekar AM, Reddy DVR, Izuka N, Amin PW, Gibson RW (1979) Bud necrosis of groundnut (A. hypogaea) in India caused by tomato spotted wilt virus. Ann Appl Biol 93: 175-179.

4. Satyanarayana T, Mitchell SE, Reddy DV, Brown S, Kresovich S, et al. (1996) Peanut bud necrosis tospovirus S RNA: complete nucleotide sequence, genome organization and homology to other tospoviruses. Arch Virol 141: 8598.

5. Fauquet CM, Mayo MA, Maniloff J, Desselberges U, Ball LA (2005) Virus Taxonomy, Eighth Report of the International Committee on Taxonomy of Viruses. (Eds,). Academic Press, San Diego, CA, USA

6. Gopal K, DQG Upadhyaya HD (1991) Effect of bud necrosis disease yield of groundnut (Arachis hypogaea L.). Indian Phytopath 32: 122-123.

7. Camann MA, Culbreath AK, Pickering J, Todd JW, Demski JW (1995) Spatial and temporal Patterns of spotted wilt epidemics in peanut. Phytopathology 85 879-885.

8. Reddy DVR, AAMT Buiel, Satyanarayana SL, Dwivedi AS, Reddy AS et al. (1995) Peanut bud necrosis virus disease: an overview. In: Buiel AAM, Parlevliet JE, Lenne JM (eds) Recent Studies on Peanut Bud Necrosis Disease, Patancheru, India, 20 March 1995, ICRISAT Asia Centre, 3-7. 
Citation: Sivaprasad Y, Bhaskara Reddy BV, Sujitha A, Sai Gopal DVR (2015) Expression and Production of Polyclonal Antibodies against Recombinant Coat Protein of Peanut bud necrosis virus. J Plant Pathol Microbiol S1: 002. doi:10.4172/2157-7471.S1-002

9. Singh AB, SK Srivatava (1995) Status and control strategy of peanut bud necrosis disease in Uttar Pradesh. In: Buiel AAM, Parlevliet JE, Lenne JM (eds) Recent studies on peanut bud necrosis disease, Patancheru, India, 20 March 1995, ICRISAT Asia Centre, 65-68.

10. Kunkalikar SR, Poojari S, Arun BM, Rajagopalan PA, Chen TC, et al. (2011) Importance and genetic diversity of vegetable-infecting tospoviruses in India. Phytopathology 101: 367-376.

11. Reddy DVR, Devi KT (2003) Viruses and Virus Like Diseases of Major Crops in Developing Countries. Peanuts. In: Thottappilly G,Loebenstein G (Eds.). Dorderecht, Kluwer Academic Publishers. 397-423.

12. Gonsalves D, Trujillo EE (1986) Tomato spotted wilt virus in papaya and detection of the virus by ELISA. Plant Dis 70: 501-506.

13. Thein $\mathrm{H}$, Bhat Al, Jain RK (2003) Mungbean necrosis disease caused by a strain of groundnut bud necrosis virus. Indian Phytopath 56: 54-60.

14. Jain RK, Paul Khurana SM, Bhat Al, Chaudhary V (2004) Nucleocapsid protein gene sequence studies confirm that potato stem necrosis disease is caused by a strain of Groundnut bud necrosis virus. Indian Phytopath 57: 169-173.

15. Okuda M, Kato K, Hanada K, Iwanami T (2006) Nucleotide sequence of melon yellow spot virus M RNA segment and characterization of non-viral sequences in subgenomic RNA. Arch Virol 151: 1-11.

16. Jain RK, Pappu HR, Pappu SS, Reddy MK, Vani A (1998) Watermelon bud necrosis tospovirus is a distinct virus species belonging to serogroup IV. Arch Virol 143: 1637-1644.

17. Nimisha Kaushal, Bhatnagar A, Tiwari Jagesh K, Kumar Deep, Kaundal Priyanka (2010) Print capture RT-PCR to detect groundnut bud necrosis virus cause of potato stem necrosis disease. Potato Journal 37: 117-120.

18. SivaprasadY Bhaskara Reddy BV, Sujitha A, Sai Gopal DVR (2013) Sequence diversity of the nucleoprotein gene of peanut bud necrosis virus isolates from the South India. J Phytopathol 162: 542-547.

19. Sambrook J, Russell DW (2001) Molecular Cloning: A laboratory manual. (3rdedn) Coldspring Harbour, Coldspring Laboratory Press, NY

20. Laemmli UK (1970) Cleavage of structural proteins during the assembly of the head of bacteriophage T4. Nature 227: 680-685.

21. Clark MF, Bar-Joseph M (1984) Enzyme immunosorbentassays in plan virology. Methods Virol 7: 51-85.

22. O'Donnell IJ, Shukla DD, Gough KH (1982) Electro-blot radioimmunoassay of virus-infected plant sap - a powerful new technique for detecting plant viruses. J Virol Methods 4: 19-26.

23. Vaira AM, Vecchiati M, Masenga V, Accotto GP (1996) A polyclonal antiserum against a recombinant viral protein combines specificity with versatility. J Virol Methods 56: 209-219.

24. Ling KS, Zhu HY, Jiang ZY, Gonsalves D (2000) Effective application of DASELISA for detection of Grapevine leafroll associated closterovirus-3 using a polyclonal antiserum developed from recombinant coat protein. Eur J Plant Pathol 106: 301-309.

25. Petrzik K, Mráz I, Kubelková D (2001) Preparation of recombinant coat protein of Prunus necrotic ringspot virus. Acta Virol 45: 61-63.

26. Gulati-Sakhuja A, Sears JL, Nuñez A, Liu HY (2009) Production of polyclonal antibodies against Pelargonium zonate spot virus coat protein expressed in Escherichia coli and application for immunodiagnosis. J Virol Methods 160: 29-37.

27. Sharma SK, Kumar PV, Baranwal VK (2014) Immunodiagnosis of episomal Banana streak MY virus using polyclonal antibodies to an expressed putative coat protein. J Virol Methods 207: 86-94.

28. Khatabi B, He B, Hajimorad MR (2012) Diagnostic Potential of Polyclona Antibodies Against Bacterially Expressed Recombinant Coat Protein of Alfalfa mosaic virus. Plant Disease 96: 1352-1357.

29. Jain RK, Pandey AN, Krishnareddy M, Mandal B (2005) Immunodiagnosis of groundnut and watermelon bud necrosis viruses using polyclonal antiserum to recombinant nucleocapsid protein of Groundnut bud necrosis virus. J Virol Methods 130: 162-164

30. Cerovska N, Moravec T, Rosecka P, Dedic P, Filigarova M (2003) Production of polyclonal antibodies to a recombinant coat protein of potato mop-top virus. J Phytophathol 151: 195-200.

31. Folwarczna J, Plchová $H$, Moravec T, Hoffmeisterová $H$, Dedic $P$, et al. (2008) Production of polyclonal antibodies to a recombinant coat protein of potato virus Y. Folia Microbiol (Praha) 53: 438-442

32. Bhat Al, Jain RK, Varma A, Lal SK (2001) Tospovirus(es) infecting grain legumes in Delhi-their identification by serology and nucleic acid hybridization. Indian Phytopathol 54: 112-116.

33. Mandal B, Jain RK, Chaudhary V, Varma A (2003) First report of natural infection of Luffa acutangula by watermelon bud necrosis virus in India. Plant Dis 87: 598.

34. Thien HX, Bhat Al, Jain RK (2003) Mungbean necrosis disease caused by a strain of Groundnut bud necrosis virus. Omonrice 11: 110-116.

35. Umamaheswaran K, Jain RK, Bhat Al, Ashwai YS (2003) Biological and molecular characterization of Tospovirus isolate from tomato and its relationship with other Tospovirus. Indian Phytopath 56: 168-173. 